\title{
Consumer demand for value-added products of African indigenous vegetables in coastal Kenya: The case of sundried and frozen cowpea leaves
}

\author{
Julius J. Okello ${ }^{\text {** }}$ \\ International Potato Center
}

Margaret J. Hutchinson, ${ }^{\mathrm{b}}$ Agnes Mwang'ombe, ${ }^{\mathrm{b}}$ Jane Ambuko, ${ }^{\mathrm{b}}$ Florence Olubayo ${ }^{\mathrm{b}}$

University of Nairobi

Martin Mwakangalu c

Kenya Agricultural Research Institute

\begin{abstract}
Submitted November 20, 2013 / Revised November 29, 2014, January 6, January 14, May 4, and
May 22, 2015 / Accepted May 22, 2015 / Published online November 12, 2015

Citation: Okello, J. J., Hutchinson, M. J., Mwang’ombe, A., Ambuko, J., Olubayo, \& Mwakangalu, M. (2015). Consumer demand for value-added products of African indigenous vegetables in coastal Kenya: The case of sundried and frozen cowpea leaves. Journal of Agriculture, Food Systems, and Community

Development, 6(1), 189-207. http://dx.doi.org/10.5304/jafscd.2015.061.004
\end{abstract}

Copyright (C) 2015 by New Leaf Associates, Inc.

\begin{abstract}
Some recent efforts to improve the food and nutrition security of rural households have focused on the promotion of African indigenous vegetables (AIVs). This has been due to the challenges smallholder farmers face in participating in highvalue global food systems. AIVs contain vitamins and micronutrients not found in most exotic vegetables, and therefore their consumption could contribute to resolving malnutrition among poor rural households. Higher consumption could also

a* Corresponding author: Julius J. Okello, International Potato Center; P.O. Box 22274; Kampala, Uganda; +256-756024761; jokello@gmail.com

b University of Nairobi, College of Agriculture and Veterinary Sciences; P.O. Box 29053-00625; Nairobi, Kenya.

${ }^{\mathrm{c}}$ Kenya Agricultural Research Institute, Mtwapa; P.O. Kilifi, Kenya.
\end{abstract}

lead to improved rural incomes through sales into urban niche markets, resulting in enhanced community development. Despite the role AIVs can play in promoting food security and community development, the AIV supply is highly seasonal, characterized by large gluts and acute shortages. Much study of AIVs has focused on production rather than consumption. In this study we use descriptive analysis to describe AIV consumers and assess demand for basic valueaddition practices by AIV retailers. We then use regression analysis to examine the factors conditioning consumers' willingness to pay (W'TP) for more advanced value-addition processes that can smooth out the supply of AIVs. It focuses on cowpea (Vigna unguiculata), one of the most widely consumed AIVs in western, eastern, and coastal Kenya. We find that several socio-economic factors and varietal attributes condition the WTP 
for value addition. Specifically, WTP is affected by age, gender, education, awareness of the selected value-addition techniques, and the self-reported likelihood of purchasing value-added vegetables. Additionally, color, tenderness of leaves, and the washing off of soil affect WTP for value addition. The paper discusses the implications of these findings for traditional fresh produce food systems, community development, and policy.

\section{Keywords}

urban consumers, willingness to pay, value added, attributes, African indigenous vegetables, AIVs, cowpea leaves, Kenya

\section{Introduction}

The need to earn revenues from foreign trade has led sub-Saharan African countries to pursue a rural development strategy that focuses on production and sale of fresh vegetables for export to developed countries. The aim of this strategy is to use export horticulture to promote employment creation (and hence income-earning opportunities), improve rural households' food security, reduce rural poverty, and thus contribute to community development. Export horticulture targets the lucrative markets of developed countries, especially those in Europe. However, over the past decade or so these efforts have faced major challenges from the imposition of stringent and continuously changing international food safety standards. Examples of these standards include the GlobalGAP, Tesco Supermarket's Nature's Choice, and Mark \& Spencer's Farm-to Folk (Okello \& Swinton, 2010). Studies indicate that these standards have tended to discourage many smallholder farmers from continued participation in global food systems because the investment costs are high in terms of human, physical, and financial capital items (Graffham \& Macgregor, 2009; Nyagah, 2009; Okello \& Swinton, 2010). This situation can contribute to entrenching household food insecurity and poverty if alternative markets do not function well.

The challenges of maintaining the participation of poor smallholder farmers in horticultural export value chains are leading to an increased emphasis in development work on domestic horticulture, including some work on African indigenous vegetables (AIVs) (Abukusta-Onyango, 2003) that until recently were neglected by policy-makers and treated as "poor women's subsistence crops," a low-value nontradable commodity, and a crop for the poor that merited no attention (Muhanji, Roothaert, Webo \& Mwangi, 2011). As the value of these crops becomes more recognized, three additional factors are contributing to the increased interest in AIVs. First, research indicates that the majority of AIVs have beneficial nutritional and medicinal properties (Irungu, Mburu, Maundu, Grum, \& Hoeschle-Zeledon, 2007; Okonya \& Maass, 2014), making them an important component of traditional food systems. Second, an increase in disposable income among middle-class consumers, who frequently demonstrate strong awareness of the importance of healthy diets rich in fruits and vegetables, together with an increase in urban populations, has led to increased demand for fresh fruits and vegetables and their valueadded products (Abukutsa-Onyango, Kavagi, Amoke, \& Habwe, 2010). As demand for AIVs has increased, so has the number of farmers who are shifting into commercial production of these crops, especially around peri-urban areas (Okonya \& Maass, 2014). Ngugi, Gitau, and Nyoro (2007) found that up to $30 \%$ of vegetables sold in Nairobi are AIVs produced in peri-urban farms. Third, the richness of some AIVs' micronutrient levels has led to their promotion as good foods for managing HIV-AIDS in adults (Irungu et al., 2007) and for addressing micronutrient deficiency problems (including vitamin A, iron, calcium, magnesium, zinc and iodine) (Hutchinson, Kipkosgei, \& Akundabweni, 2011) in young children and lactating mothers (Flyman \& Afolayan, 2006; Müller \& Krawinkel, 2005). AIVs help to tackle the problem of malnutrition because they provide important key micronutrients.

Furthermore AIVs have attracted the attention of agencies focused on community development because they are mostly grown by smallholder farmers who make up a majority of the poor in farming communities. Among these, women are a majority (Abukutsa-Onyango, 2002; Irungu et al., 2007; Weinberger, Pasquini, Kasambula, \& Abukutsa-Onynago, 2011). Studies conducted in 
the three East African countries find that more than $73 \%, 69 \%$, and $65 \%$ of AIV farmers in Kenya, Uganda, and Tanzania, respectively, are women (Abukutsa-Onyango, Kavagi, Amoke, \& Habwe, 2010; Weinberger et al., 2011). Since women play important roles in household food provisioning, and in rural food systems in general (Johns \& Sthapit, 2004), it is arguable that the development of this subsector can significantly contribute to household food security and poverty reduction by enhancing the effectiveness of their role. At the same time, the tolerance of most AIVs to a wide spectrum of abiotic and biotic stresses makes them more suited to smallholders' low-input production techniques than their exotic counterparts, which frequently require pesticides and fertilizers and an adequate supply of water to perform well. Interest in AIVs is being further driven by health consciousness among the more affluent urban consumers who associate these vegetables with a low risk of pesticide and pathogen contamination (Karanja, Njenga, Mutua, Lagerkvist, Kutto, \& Okello, 2012).

The importance of AIVs in the current development agenda is further illustrated by the interest they have attracted among the donor community. Donor interest is translating into significant support for projects that promote production and marketing of AIVs in African countries, including Kenya. The International Development Research Center, the Bill and Melinda Gates Foundation, the United States Agency for International Development, and the Food and Agriculture Organization of the United Nations have recently supported programs and projects that target the improvement of AIV value chains in many African countries. In Kenya, Farm Concern International, the University of Nairobi, Jomo Kenyatta University of Agriculture and Technology, Egerton University, and the Kenya Agricultural Research Institute are some of the organizations with projects focusing on the development of AIV value chains. A major area of focus of these projects is increased production through better agronomic practices; improved postharvest processing and quality preservation; value addition through various processing options; and retailing practices. Processing and value addition is especially intended to ameliorate the sea- sonal fluctuations in supply (Kumar, Singh, Kumar, \& Mittal, 2011).

Despite the strong interest and donor support for the development of AIV value chains, the literature remains very scanty on demand for valueadded AIV products. Studies to date have tended to focus primarily on production and marketing segments of the value chain (Abukusta-Onyango, 2003; Abukutsa-Onyango et al., 2010; Muhanji et al., 2011; Mundua, 2010) and less on consumption and demand for AIVs. Only a few studies have examined the importance of value addition to consumers. Matenge, van der Merwe, De Beer, Bosman, and Kruger (2012), for instance, use hedonic scaling to evaluate consumer preference and acceptance of AIVs. Mundua (2010), on the other hand, assesses consumer WTP for cowpea varieties. Neither study, however, focuses on the WTP for value addition. This study fills this knowledge gap by assessing demand for value addition by consumers in urban markets. It specifically characterizes urban consumption and demand for basic value-addition practices at the retail level, and then examines demand for more advanced valueaddition processes specifically meant to make AIVs available during dry seasons when the green leaves are usually unavailable. By focusing on the consumer end of the chain, this paper adds value to the literature on AIVs and on value-chain development more broadly.

This study is based on data collected from urban consumers of cowpea leaves in main market outlets in Mombasa and Kilifi districts in coastal Kenya. Cowpea is one of the main fresh vegetables consumed by both urban and rural residents in both districts. It is the third most consumed vegetable by urban consumers after kale and amaranth, and also by rural producers and consumers in the two districts, making it an important component of both rural and urban food systems. It is especially popular among Mijikenda ethnic communities, where a majority of people consume it as boiled leaves, usually cooked in coconut milk. The supply of cowpea leaves, however, is currently highly seasonal, with glut experienced during the rainy season (approximately April to August) and acute shortages during the dry period (approximately December to March). The leanest months in terms 
of availability of cowpea leaves are January and February, the peak of the dry season in the study areas. These fluctuations in supply mean that market prices vary widely over the season and are usually highest during the peak of the dry season. One strategy to smooth out the supply, reduce postharvest losses, and ensure availability of cowpea leaves even during the dry season is through processing.

There are various available options for processing cow peas. These include air- or sun-drying, solar drying, greenhouse drying, freezing, and freeze-drying. Each of these processing options affects the nutritional and aesthetic quality of cowpea leaves differently, and consequently affect consumer acceptance and demand. This study therefore sought to determine if consumers would pay for value-addition strategies that would enable cowpea leaves to be available during the dry season. The rest of this paper is organized as follows: Section 2 outlines the theory and methods used. Section 3 discusses the data, and Section 4 presents and discusses the results. Section 5 concludes and highlights key policy implications.

\section{Research Methods}

This study draws from consumer theory following Lancaster (1966) and several recent studies that argue that individuals obtain utility from the benefits a good delivers, that is, its characteristics (for instance, in our case, time utility) rather than only from the good per se (Akgüngör, Miran, \& Abay, 2007; Lacaze, Rodríguez, \& Lupín, 2009; Lippe, Mergenthaler, \& Isvilanonda, 2010; Lusk \& Hudson, 2004; Takatsuka, Cullen, Wilson, \& Wratten, 2009). These studies specifically posit that consumers derive satisfaction not only from the good itself but also from the attributes or characteristics of the good. In the context of this study, willingness to pay is defined as the resources individuals are willing and able to give up for value addition. It encompasses the availability of food of a desired quality (and desired time and amounts). Thus value addition is conceived of as a process that makes food of desirable quality available at the desired time, quality, and quantity.

Consumer theory further posits that consumers will balance the additional benefits associated with value addition and the increase in the unit price of a value-added food. The marginal utility of value addition, on the other hand, depends on consumers' socio-economic characteristics, learning abilities (i.e., the ability to process information), and exposure levels to food-borne hazards (Blend \& Ravenswaay 1998; Gao \& Schroeder, 2009). WTP is therefore interpreted as an indicator of demand for value-added vegetables. Indeed, Gracia, Loureiro \& Nayga (2009) suggest that consumers' abilities to process information affect their evaluation of product information, and hence products, while Eom (1994) found that consumers' stated preferences (i.e., utility) are affect by information about risk of pesticide exposure.

Stated WTP $\left(P_{i}\right)$ for cowpea leaves for each consumer $i$ was used as the dependent variable in the study. $P_{i}$ is interpreted as the additional money that consumer $i$ is willing to pay for the valueadded cowpea leaves. It is assumed that estimates of implicit values of characteristics can be used to estimate the price of an unobserved product by valuing embodied characteristics, namely value addition in this case (Hanley, Wright, \& AlvarezFarizo, 2006). In this study, separate WTP models were estimated for sundried cowpea leaves and frozen cowpea leaves. The functional form of the model estimated is specified as

$\mathrm{P}_{\mathrm{i}}=\alpha+\mathrm{X}_{\mathrm{i}} \beta_{\mathrm{i}}+\mathrm{Z}_{\mathrm{i}} \gamma_{\mathrm{i}}+\varepsilon$

Where,

$P_{i}=$ stated marginal WTP for a bundle of valueadded cowpea leaves in Kenya shillings. ${ }^{1}$ That is, $P_{i}$ is the additional amount of money a consumer is willing to pay,

$X_{i}=$ a vector of consumption attributes preferred by the consumer,

$\beta_{i}=$ the estimated coefficient on the consumption attributes,

$Z_{i}=$ a vector of household socio-economic characteristics,

$\gamma_{i}=$ the estimated coefficients for household socioeconomic characteristics, and

$\varepsilon=$ Stochastic error term.

${ }^{1}$ US $\$ 1$ was equivalent to 85 Kenya shillings at the time of this study. 
The variables ( $\mathrm{X}$ and $\mathrm{Z}$ ) used in the estimation of the model in Equation 1 were selected based on the literature and are:

1. Socio-economic variables $(\mathrm{Z})$ : Inage $=$ natural $\log$ of age of the respondent in years; gender $=$ dummy variable equal to 1 if the respondent is male, 0 otherwise; memgrp $=$ dummy variable equal to 1 if the purchaser is a member of a social/consumer group, 0 otherwise; lnincome = natural log of income earned by the purchaser's household in 2011 in Kenya shillings; drymthd = dummy equal to 1 if the purchaser is aware of sun-drying method of value addition, 0 otherwise; freezmthd $=$ dummy equal to 1 if the purchaser is aware of freezing method of value addition, 0 otherwise; buydry = dummy equal to 1 if the purchaser would buy sundried vegetable, 0 otherwise; buyfrozen $=$ dummy equal to 1 if the purchaser would buy frozen vegetable, 0 otherwise; info = dummy equal to 1 if purchaser has ever received information about value addition in vegetables from any source; 0 otherwise; qntyconsmd = quantity of cowpea leaves consumed by the household in bundles.

2. The consumption attribute variables $(\mathrm{X})$ include: clean $=$ dummy equal to 1 if a purchaser prefers clean (nonsoiled) leaves, 0 otherwise; taste $=$ dummy equal to 1 if a purchaser prefers good taste, 0 otherwise; color $=$ dummy equal to 1 if a purchaser prefers leaves that have goodlooking (green) color, 0 otherwise; tender $=$ dummy equal to 1 if a purchaser prefers leaves that are young and/or tender, 0 otherwise; uninjured = dummy equal to 1 if a purchaser prefers leaves that are uncrushed, uninjured, and/or unbruised, 0 otherwise; price $=$ dummy equal to 1 if a purchaser prefers a fair price, 0 otherwise.

3. Since the dependent variable (willingness to pay) is a continuous variable that is censored at 0 , i.e., there are zero values for consumers who are not willing to pay anything for value addition, the Tobit regression models were estimated separately for the sundried and frozen cowpea.

In order to test for differences in WTP between frozen and sundried cowpea leaves, the Wilcoxon Signed Rank test was used. This nonparametric test examines whether subsamples, in this case WTP for sundried and frozen cowpeas, generated from the same population are different (Rosner, Glynn, \& Lee, 2006). In addition, following Wooldridge (2010, p. 450), we use the Wald test of multiple exclusion restriction to test whether variables that are statistically insignificant, and do not appear to contribute to the variability in the WTP, can be jointly excluded from the regressions model.

\section{Data and Scenario Description}

This study was conducted in Kongowea, Mtwapa, Kilifi, Majengo, and Saba Saba markets in coastal Kenya. The four markets control the greatest share $^{2}$ of the vegetables traded in Mombasa and Kilifi districts. Data were collected via personal interviews by trained enumerators using predesigned and pretested questionnaires. The sampling procedure was as follows: In each market the respondents were selected from among the purchasers of cowpea leaves using random sampling techniques. Specifically, every third person who purchased cowpea leaves was picked and interviewed. This was continued until the predetermined quota of 15 purchasers was interviewed in each day.

The interviews were conducted at different times of the day (morning (from about 7:00 am), noon, and afternoon to evening (ending at about 5:30 pm)), and were also conducted on both weekdays and weekends in order to capture different consumer buying patterns. In markets that are expansive and/or where cowpea leaves were sold at different locations, the market was divided into four zones and an interviewer was stationed in each zone. The interviewer then interviewed every third person who bought cowpea leaves in that zone. A total of 147 consumers were interviewed.

On average, one in every five cowpea buyers approached for interviews declined to participate in the study, resulting in a nonresponse rate of $20 \%$.

2 Other channels through which cowpea leaves are traded in the study areas are (a) street peddlers (i.e., mama mboga) and (b) kiosks. Due to time, financial, and logistical reasons, this study did not interview purchasers who use these channels. 
The most commonly cited reason for refusing to take part in the study was lack of time. For respondents who were willing to participate, data were collected on, among other things, WTP for value-added cowpea leaves, and the socioeconomic factors and consumption attributes likely to affect WTP for value addition in cowpea. The interviews were conducted in April and May 2012.

This study used the payment card method in collecting the WTP data. Past studies mainly used the dichotomous choice method in collecting WTP bids. However, the dichotomous choice method usually obtains very little information from each respondent and hence is inefficient (Ngigi, Okello, Lagerkvist, Karanja, \& Mburu, 2011). Multiplebounded dichotomous choice approaches, an improvement on earlier models, nevertheless have the drawback that they yield internally inconsistent responses. The payment card approach overcomes these challenges by improving the efficiency of the WTP estimates (Kerr, 2000). It also has the additional advantage of being simple to implement while minimizing the probability of starting-point bias found in interactive bidding techniques.

The payment card had these instructions:

On this sheet are written different amounts of money from zero up to more than 10 Kenyan shillings (Ksh). Starting at the top of the list and moving down kindly ask yourself: 'Am I willing to pay $1 \mathrm{KSh}$ over and above what I would pay for a standard heap of cowpea leaves in order to buy similar amount of value-added cowpea leaves?' If you are certain you would pay the amounts of money in the card to buy the value-added cowpea leaves then place a tick $(\sqrt{ })$ in the space next to the amount you will be willing to pay. Please tick only when you are sure
Table 1. Payment Card Illustrating the Distribution of Willingness To Pay Scenario 3: Frozen/vacuum-packed cowpea leaves

\begin{tabular}{cc} 
Sundried cowpea leaves & cowpea leaves \\
\hline 0 shilling/heap & 0 shilling/heap \\
\hline 1 shilling/heap & 1 shilling/heap \\
\hline 2 shilling/heap & 2 shilling/heap \\
\hline 3 shilling/heap & 3 shilling/heap \\
\hline 4 shilling/heap & 4 shilling/heap \\
\hline 5 shilling/heap & 5 shilling/heap \\
\hline 6 shilling/heap & 6 shilling/heap \\
\hline 7 shilling/heap & 7 shilling/heap \\
\hline 8 shilling/heap & 8 shilling/heap \\
\hline 9 shilling/heap & 9 shilling/heap \\
\hline 10 shilling/heap & 10 shilling/heap
\end{tabular}

More than 10 shilling/heap More than 10 shilling/heap

you can keep paying this additional amount even in future.

The payment card used for eliciting responses, along with the various WTP bids, is presented in Table 1.

The three scenarios presented to consumers were:

Product Scenario 1 (Normal/standard cowpea leaves): This product is grown using standard production practices. It is abundant during the rainy season, and hence the amount of leaves in a bundle or heap costing KSh10 is large. It is therefore very cheap during the rainy season. However it is not easily available during dry season, and when found, the leaves are hard, fibrous, and small. The bundle size selling for KSh10 during the dry period is very small. ${ }^{3}$

Product Scenario 2 (Sundried cowpea leaves): This product is grown using standard production practices. However, it is preserved through open sun-drying, and hence the leaves are brownish. The dried leaves are hygienically stored. How-

\footnotetext{
${ }^{3}$ The normal practice is for fresh vegetable retailers to reduce the size of the bundle rather than the price during times of scarcity (such as the dry period).
} 
ever, due to drying, leaves from a regular bundle or heap look small. There is, however, no difference in the amount of vegetables once it is cooked. This product is therefore readily available during the dry season.

\section{Product Scenario 3 (Blanched and} vacuum-packed frozen cowpea leaves): This product is produced using standard production practices. However, it is preserved by being frozen after blanching and vacuum-packing. The preserved cowpea leaves retain their green color and tenderness. Preservation makes it possible to store the product for longer periods; thus this product is available even during dry season.

One of the most often cited criticisms of WTP bids elicited using hypothetical situations is the hypothetical bias. In this study, we use "cheap talk" proposed by Cummings and Taylor (1999) and subsequently applied by List (2001) and Chowdhury, Meenakshi, Tomlins, and Owori (2011) to mitigate such bias. Specifically, the respondents were advised to select the additional payment only if they were prepared to pay it regularly. Such warnings significantly reduce or even eliminate the problem of hypothetical bias (Chowdhury et al., 2011).

This study also examined some of the basic value-addition practices undertaken by cowpea leaf retailers and traders and the willingness by consumers to pay for such practices. The basic valueaddition activities examined included: (a) presenting the vegetable on a raised bed (i.e., wooden structure or frame with a flat top about three feet or one meter from the ground), (b) chopping the leaves, (c) grading and/or sorting, (d) packaging well, (e) washing the produce and (f) destalking (i.e., plucking the leaves from the stalks). WTP for these practices was assessed using a binary dummy variable equal to 1 (=Yes) if a respondent was willing to pay for a basic value-addition practice, and 0 otherwise.

\section{Results and Discussion}

\section{Characteristics and Consumption Patterns \\ of Compea Leaf Consumers}

Table 2 presents the variables used in the analysis and estimation of the econometric models along with the results of summary statistics that characterize the purchasers interviewed.

The summary statistics indicate that the average WTP for value-added cowpea leaves (i.e., both sun-drying and freezing) is approximately KSh5.00 per heap, with a standard deviation of 4 . That is, the respondents are willing to pay an extra KSh5.00 per heap with value addition. Results further show that the minimum WTP for both forms of value addition is $\mathrm{KSh} 0$ (zero), indicating that there are some consumers who did not attach any value to the processes that will make cowpea available during dry seasons, when it is usually very difficult to find in the market. Indeed, $34 \%$ and $44 \%$ of consumers indicated that they would pay nothing (i.e., KSh0) for sundried and frozen cowpea leaves, respectively. The summary statistics further show that the average age of the respondents is 31 years, suggesting that many of cowpea leaf consumers are young. Results also show that the respondents, on average, have 10 years of education, earn KSh21,000 per annum, and are mostly women. The low annual income of the cowpea consumers is not surprising and has often been interpreted to mean that cowpea is an inferior, low-value good. In addition, the finding that most of the respondents are females indicate that shopping for vegetables is done mostly by women. This is in line with findings involving urban vegetable purchasers in Kenya (Lagerkvist, Hess, Okello, Hansson, \& Karanja, 2013).

Table 3 presents the frequency of consumption of cowpea leaves by the respondents. Most households consume cowpea 2 to 3 times per week. Overall, 69 and 64 of the 147 respondents consume cowpea leaves 2 to 3 times per week and at least once per week, respectively. Results further reveal no major gender differences among the survey respondents other than slightly more males consuming cowpea leaves 2 to 3 times per week. Analysis of the frequency of consumption of other vegetables showed similar results. Results also indicate that most consumers have a greater preference for clean (i.e., those with any soil washed off) and tender cowpea leaves, and pay much less attention to the color of the leaves. 
Table 2. Summary Statistics of the Variables Used in the Study Consumers' Willingness to Pay for Value Addition in Cowpea $(\mathrm{N}=\mathbf{1 4 7})$

\begin{tabular}{|c|c|c|c|}
\hline Variable & Variable Description & Mean & Std. Dev. \\
\hline wtpdry & Willingness to pay for sun-drying & 4.74 & 4.12 \\
\hline wtpfrozen & Willingness to pay for freezing & 4.83 & 4.45 \\
\hline age & Age of the respondent (years) & 31 & 9.58 \\
\hline gender & Gender of the respondent ( $1=$ male, $0=$ female $)$ & 0.24 & 0.43 \\
\hline hhldsize & Household size (head count) & 3 & 2.03 \\
\hline education & Education (years of schooling) & 9.76 & 4.31 \\
\hline under5 & Children below age five (head count) & 0.69 & 0.80 \\
\hline memgrp & Member to social organization $(1=\mathrm{Yes}, 0=\mathrm{No})$ & 0.50 & 0.50 \\
\hline info & Access to information ( $1=$ Yes, $0=$ No) & 0.40 & 0.49 \\
\hline income & 2011 income in Kenya shillings* & 21,147 & 28,500 \\
\hline clean & Clean leaves & 0.82 & 0.39 \\
\hline taste & Taste is good $(1=$ Yes, $0=\mathrm{No})$ & 0.25 & 0.44 \\
\hline tender & Tender leaves $(1=\mathrm{Yes}, 0=\mathrm{No})$ & 0.09 & 0.29 \\
\hline price & Price is is fair or low $(1=$ Yes, $0=\mathrm{No})$ & 0.25 & 0.44 \\
\hline uninjured & Uninjured and/or uncrushed leaves $(1=\mathrm{Yes}, 0=\mathrm{No})$ & 0.85 & 0.36 \\
\hline color & Color is attractive $(1=\mathrm{Yes}, 0=\mathrm{No})$ & 0.56 & 0.50 \\
\hline freemthd & Aware of freezing method $(1=\mathrm{Yes}, 0=\mathrm{No})$ & 0.51 & 0.50 \\
\hline drymthd & Aware of drying method ( $1=$ Yes, $0=$ No) & 0.79 & 0.41 \\
\hline buyfrozen & Would buy frozen vegetable ( $1=$ Yes, $0=\mathrm{No})$ & 0.83 & 0.38 \\
\hline buydried & Would buy sundried vegetable $(1=\mathrm{Yes}, 0=\mathrm{No})$ & 0.46 & 0.50 \\
\hline qntyconsmd & Qunatity of kale consumed (count) & 1.99 & 0.91 \\
\hline consmfreq & Frequency of cowpea consumption (count) & 2.45 & 0.73 \\
\hline
\end{tabular}

* US $\$ 1$ was equivalent to 85 Kenya shillings at the time of the study.

Table 3. Frequency of Purchase of Cowpea Leaves by Respondents' Households ( $N=147)$

\begin{tabular}{lccc}
\hline & \multicolumn{2}{c}{ Gender (count) } & \\
\cline { 2 - 3 } Frequency & Female & Male & Total \\
\hline Daily & 5 & 3 & 8 \\
\hline 2 to 3 times per week & 50 & 19 & 69 \\
\hline At least once per week & 51 & 13 & 64 \\
\hline Monthly & 4 & 1 & 5 \\
\hline Seldom & 1 & 0 & 1 \\
\hline Total & 111 & 36 & 147 \\
\hline
\end{tabular}

Cowpea leaves are mostly eaten fresh (Figure 1). Overall, more than $93 \%$ of the respondents cook cowpea leaves immediately after or on the same day of purchase. The immediate preparation 
Figure 1. Time Taken Before Cooking Purchased Cowpea Leaves (Count), by Gender $(\boldsymbol{N}=\mathbf{1 4 7})$

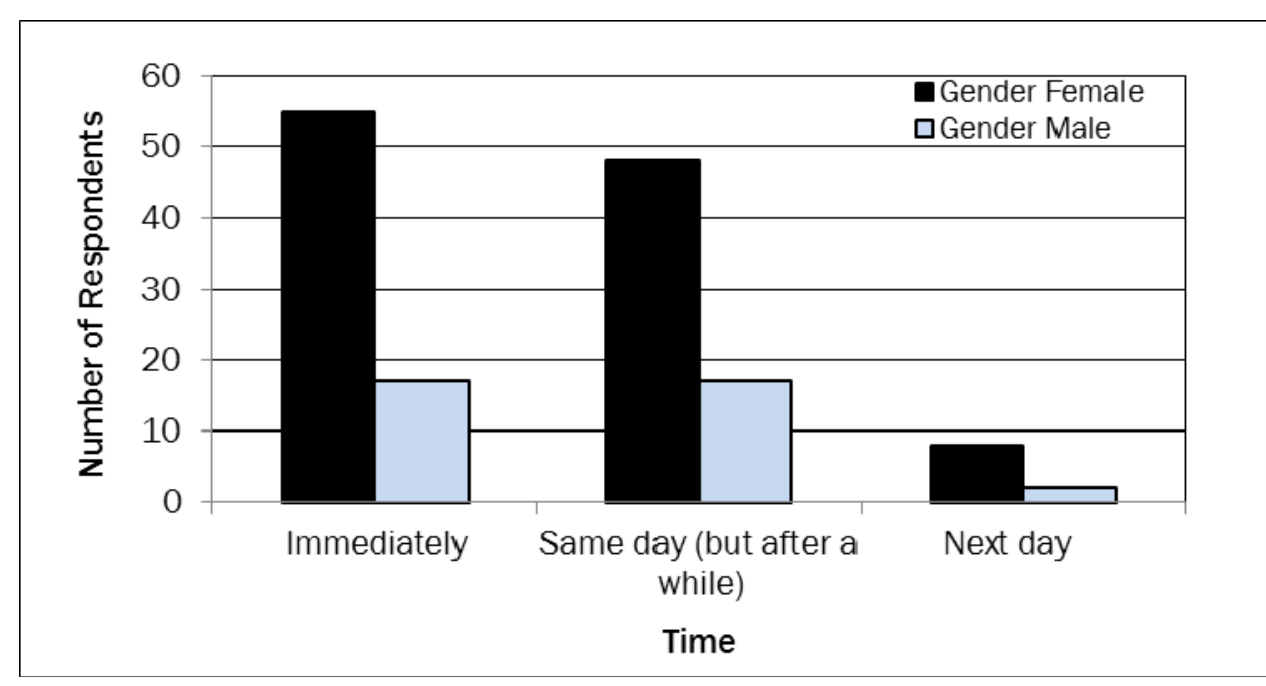

Table 4. Willingness to Pay for Basic Value-Addition Services (\%) Among Urban Consumers of Cowpea Leaves $(N=147)$

Type of value addition

Do you need this service?

(\% of Yes responses)

\begin{tabular}{llc}
\hline Hygiene (sprinkled with clean water) & 96.6 & 17.7 \\
\hline Washed produce & 91.8 & 18.4 \\
\hline Presentation style (raised bed) & 90.5 & 18.4 \\
\hline Good packaging & 88.4 & 6.8 \\
\hline Graded and sorted & 87.1 & 16.3 \\
\hline Destalked & 35.4 & 14.3 \\
\hline Chopped & 25.2 & 4.8
\end{tabular}

cowpea leaves for a variety of reasons, namely taste, health, nutrition, ${ }^{4}$ and price. Specifically, 39\% of the respondents indicated that they eat cowpea leaves because of good taste, $35 \%$ because they perceive cowpea leaves to be healthy to eat, and 11\% because they are nutritious. These findings indicate, in general, that most of the study respondents prefer cowpea leaves because of health and taste and therefore corroborate the results of a past study (Okello, Lagerkvist, Hess, Ngigi, \& Karanja, 2011)

The ethnic background of respondents also affects their consumption of cowpea leaves. More than $78 \%$ of the 57 is mainly intended to preserve taste and tenderness. The timing of cooking is important to a valueaddition strategy that would keep produce longer but also change the color, taste, or tenderness. Indeed, $63 \%$ of the respondents ranked young leaves, and tenderness and freshness of the leaves, as the most important attribute they look for in cowpea.

Results also indicate that only $5 \%$ of consumers value the color of the leaves. This finding has positive implications for value-addition processes that affect the color of the leaves, such as sun-drying. Nonetheless, sun-drying is also likely to affect the tenderness of the leaves, which is ranked highly by about $14 \%$ of the respondents.

Results further indicate that consumers eat respondents who identified taste as the main factor were from the native Mijikenda tribes and those originally from western Kenya (i.e., the Luo, Luhya, and Kisii). This finding is in line with the researchers' a priori expectations, since cowpea leaves are widely eaten in these regions. The results further show that $51 \%$ of the respondents from western, 67\% from coastal, and 42\% from central Kenya eat cowpea leaves because they consider them healthy and/or nutritious. Analysis by gender

${ }^{4}$ Health in this case mainly meant preventing one from falling sick. Nutrition, on the other hand, was used to refer to the nutrients supplied by the vegetable. While nutrition presupposes good health, the respondents in this study treated the two aspects differently. 
revealed the same trend, with $40 \%$ and $38 \%$ of women indicating that they eat cowpea leaves in preference to other vegetables because of taste and health/nutrition, respectively, while $26 \%$ and $25 \%$ of men eat cowpea due to taste and health/nutrition, respectively.

\section{WTP for basic value-addition practices undertaken by retailers of compea leaves}

Results of the assessment of respondents' WTP for the basic value-addition practices and services by percentage are presented in Table 4.

The majority of the respondents indicated that they needed most of the basic value-addition services. Indeed, more than $88 \%$ of the respondents wanted fresh cowpea leaves moistened using clean water, sold in raised beds, cleaned to remove soil, and graded and sorted. The exceptions were destalking and chopping, which were needed by only $35 \%$ and $25 \%$ of the respondents, respectively. The low WTP for these two services could be attributed to the fact that cowpea leaves spoil faster after they are chopped, unlike kale, where the practice is very common. Table 3 further shows that despite the high demand for some of the basic value-addition practices, no more than $18 \%$ of the respondents were willing to pay for any of these services. Only $4 \%$ of the respondents were willing to pay for chopping of the leaves. This finding may be related to the above argument that the quality of cowpea leaves deteriorates much faster when they are chopped. Overall, these findings indicate that there is no effective demand for the basic valueaddition services.

Results of the analysis of the demand for the more advanced value-addition processes are presented in Figure 2. These value-addition processes included (a) direct sun-drying, (b) blanching and sun-drying, (c) freezing blanched leaves, (d) freezing fresh leaves, and (e) vacuum-packing fresh leaves.

Figure 2 shows that the majority of the respondents would occasionally buy sundried cowpea leaves. However, more than $70 \%$ would not buy freshly frozen or fresh vacuum-packed cowpea leaves. Given the earlier finding that most consumers prefer young and tender leaves and often cook the cowpea leaves immediately after harvest or purchase, we had hypothesized that consumers would purchase products that are not adversely transformed by value addition. Thus the direct sundried leaves, which tend to be brown, were expected to be less attractive hence less preferred. Figure 2, however, presents a different picture. It shows that most of the respondents would purchase sundried leaves either occasionally or all the time. Indeed, while $67 \%(N=147)$ of consumers indicated that they would buy fresh

Figure 2. How Often Would You Buy Value-Added Cowpea Leaves? (count; $N=147$ )

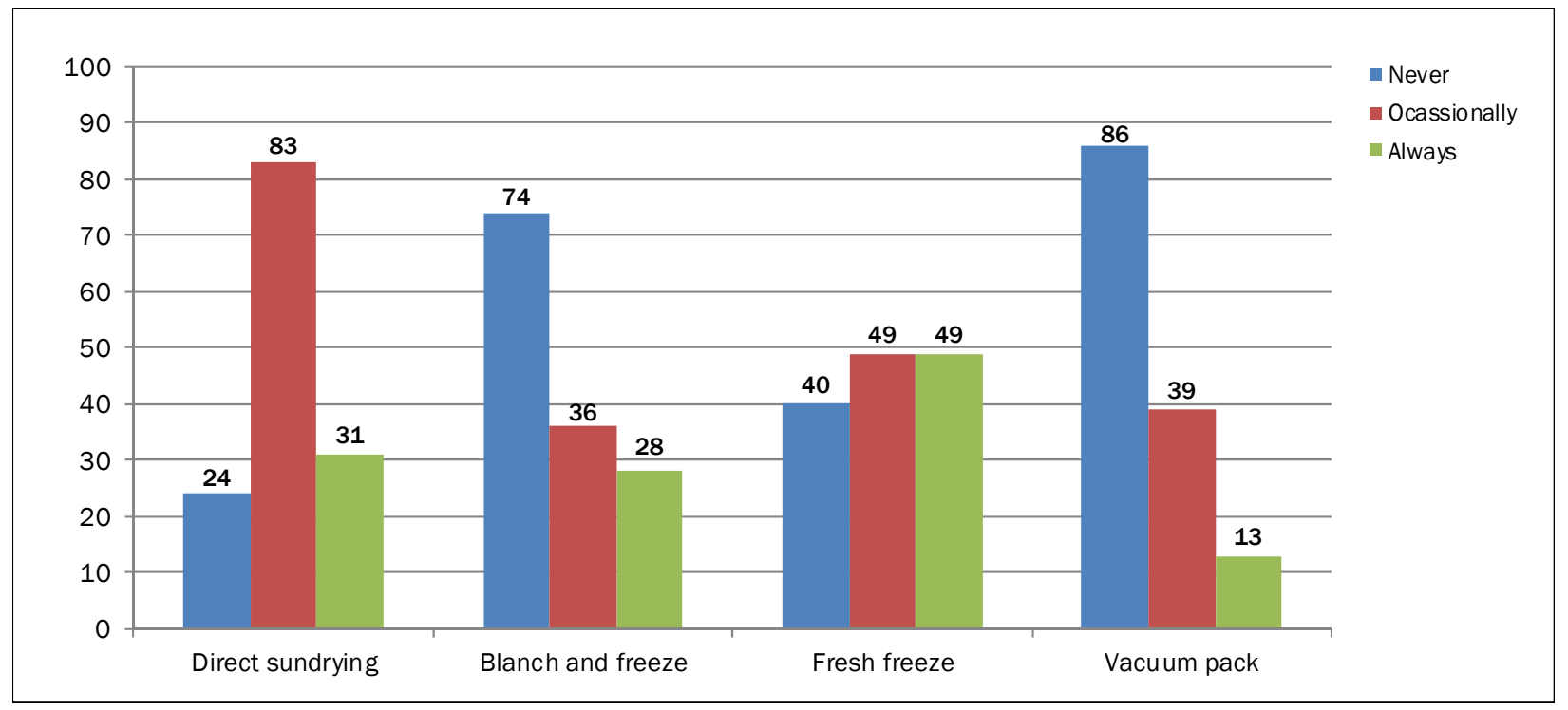


Figure 3. Have You Ever Heard of the Following Value-Addition Activities? (\%, $N=147)$

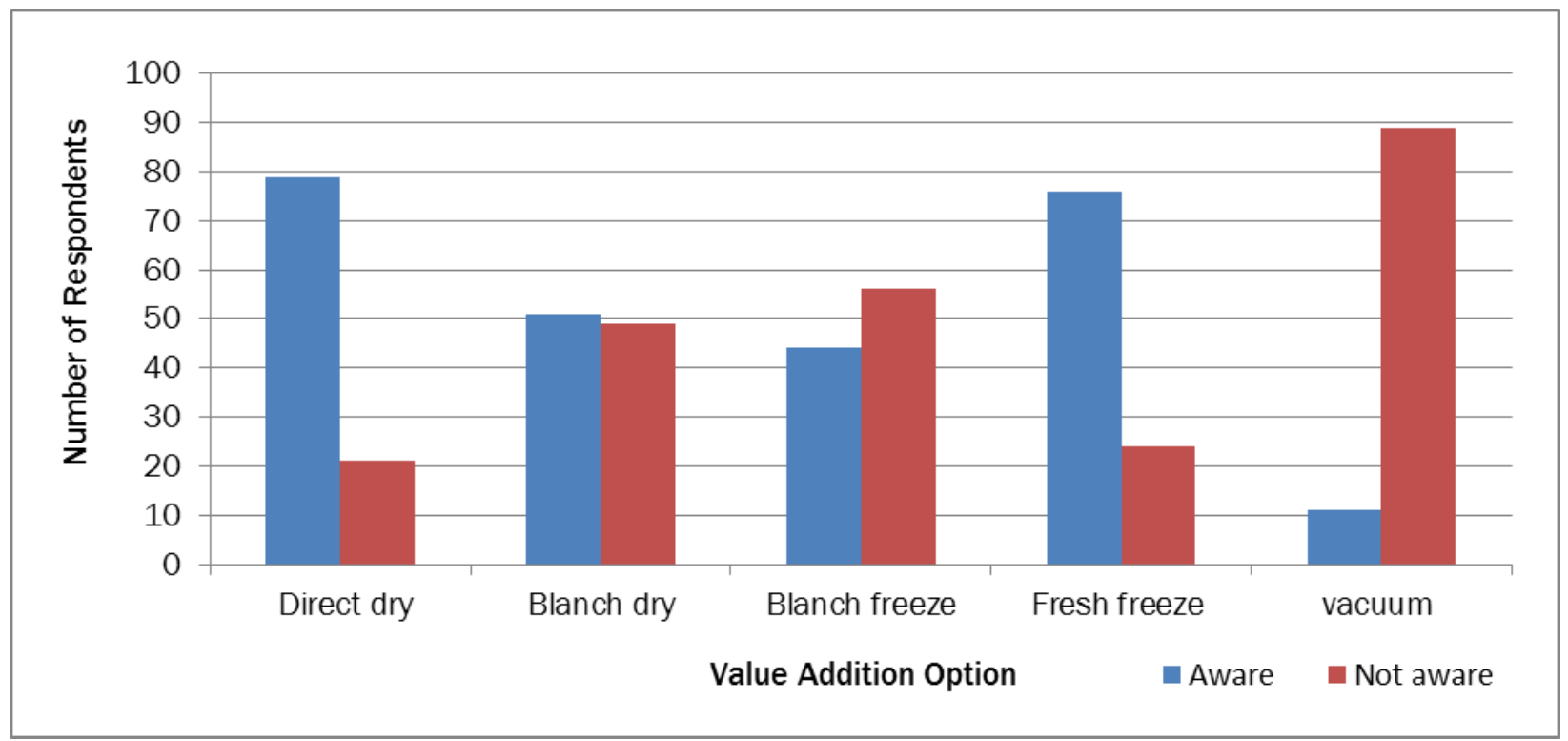

frozen cowpea leaves always or once in a while, a majority of the respondents would not buy the fresh vacuum-packed or blanched-and-frozen cowpea leaves at all. These contradictions may be due to the respondents' unfamiliarity with some of these value-addition technologies. It is also likely that the respondents linked the processing with high purchase prices, since value-added products tend to be associated with supermarkets rather than open-air (wet) markets, and hence are likely to be more expensive.

Analysis of awareness among cowpea leaves consumers of these more advanced value-addition processes is shown in Figure 3. It shows that a majority of the consumers have heard of the direct sun-drying and fresh freezing of cowpea leaves. However, most respondents were unfamiliar with the process of blanching and drying or blanching and freezing vegetables, while only a few had heard of vacuum-packing fresh vegetables. These find-

Figure 4. How Often Would You Buy Value-Added Cowpea Leaves? (count; $N=147$ )

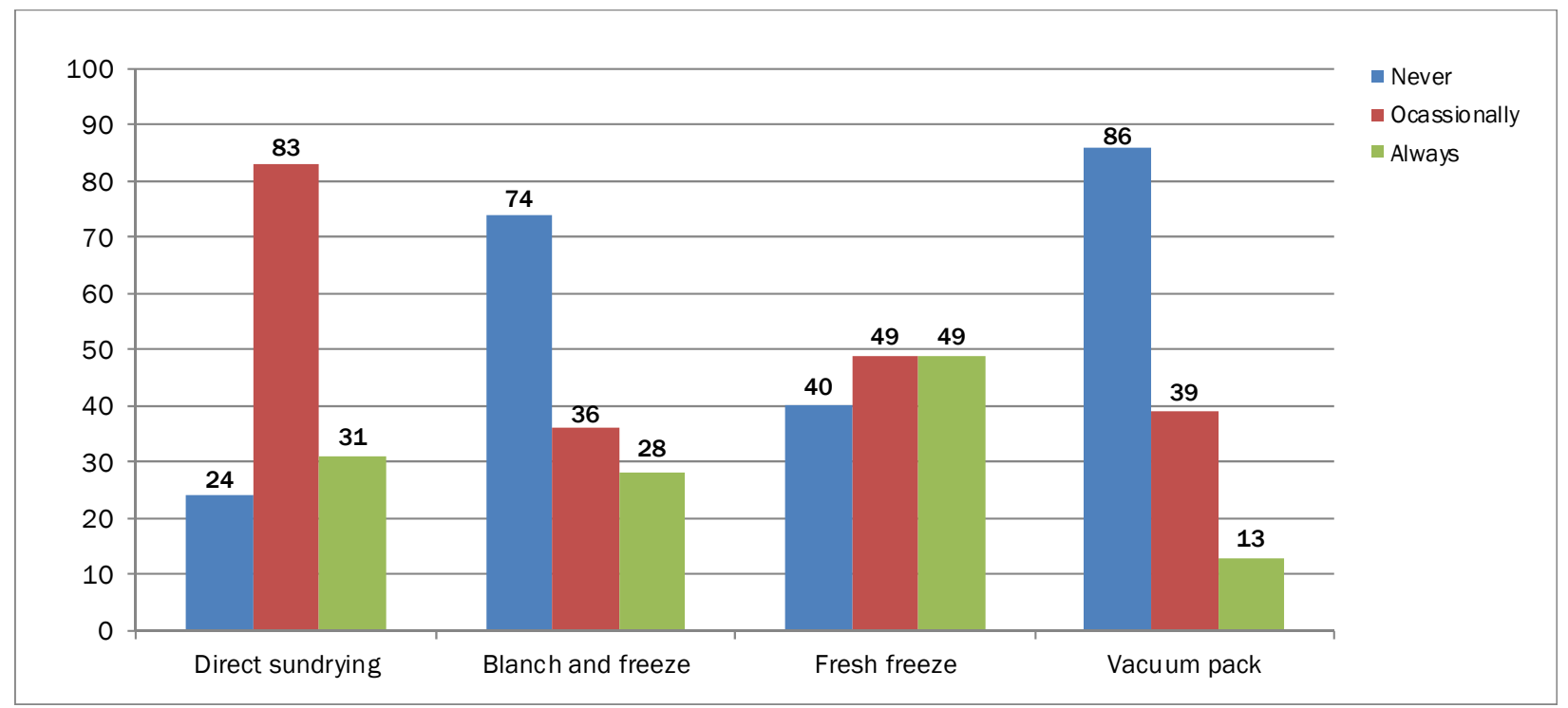


ings indicate the need to educate consumers about the advantages and disadvantages of these techniques before training farmers and processors in their use. Blanching prior to drying and freezing stops enzymatic activities and hence fixes and retains the green color of the leaves. Freezing, as opposed to drying, the blanched vegetables minimizes the loss of water-soluble vitamins. Lack of awareness of these facts could lead consumers to underrate the importance of value addition in enhancing their own health. The data further reveal that nearly half of consumers (46\%) would buy direct sundried cowpea leaves even if products from the other options were available and sold at the same price. Only about $9 \%$ of respondents would buy blanched and frozen cowpea leaves.

Figure 4 shows that among the 147 consumers interviewed, only $18 \%$ have ever bought prepacked vegetables in the supermarket. Analysis of the most preferred shopping outlet indicates that only $1 \%$ of the study respondents buy fresh vegetables at a supermarket, the only outlet that sells frozen vegetables (Okello, Narrod, \& Roy, 2007). The most preferred shopping outlets were wet markets. These markets tend to be closer to consumers (and hence easier to access) and offer consumers fresh cowpea leaves at cheaper prices (Figure 4).

The distribution of consumers' WTP for the more advanced value-addition processes (i.e., dried and frozen cowpea leaves) is shown in Table 5. The Wilcoxon Signed Rank test showed that there is no difference in WTP for the two value-addition methods as compared to the alternative hypothesis that differences exist in the WTP, by yielding a $z^{-}$ statistic of 1.16 and a $p$-value of 0.244 . These results indicate that there is no statistical difference in WTP for sundried and frozen cowpea leaves.

Two key observations emerge from the data in Table 5. First, the nature of the sale of cowpea leaves is related to the WTP values. All traders sold cowpea in bundles or heaps and at a price of KSh10 per bundle or heap. The bundle or heap sizes varied among traders and markets, but the unit price did not change. This selling practice is reflected in the WTP bids the consumers stated. Specifically, the WTP data are clustered around the values of 0,5 and 10 , which are factors of 10 , suggesting that consumers could relate more with values that reflected how much they currently pay for a bundle of the produce.

Second, at least one-third of the consumers interviewed were not willing to pay anything extra for the frozen cowpea leaves, while $23 \%$ were unwilling to pay anything extra for dried cowpea leaves. The higher proportion of consumers unwilling to pay for frozen leaves could, as argued earlier, suggest unfamiliarity with the technology, rather than actual lack of demand for frozen cowpea leaves. We had expected that more respondents would prefer frozen leaves to dried leaves because freezing preserves both the color and tenderness, while drying does not. However, the data do not reveal such differences. The only exception was the responses of permanently employed consumers. Among such consumers, the mean WTP for sundried and frozen cowpea leaves was KSh5.5 per bundle and KSh7.25 per bundle, respectively. The overall WTP for both forms of value-addition is KSh5/bundle. 
Table 6. Factors Affecting Willingness To Pay for Advanced Value-Addition Processes: Tobit Regression Models

\begin{tabular}{lcccc}
\hline & \multicolumn{2}{c}{ Sun-drying } & \multicolumn{2}{c}{ Freezing } \\
\hline Variable & Coeff. & p-value & Coeff. & $p$-value \\
\hline Socioeconomic variables & & & & \\
\hline gender & 1.68 & 0.062 & 0.59 & 0.579 \\
\hline Ineducation & 0.46 & 0.169 & 0.95 & 0.025 \\
\hline Inincome & -0.05 & 0.781 & -0.11 & 0.621 \\
\hline memgrp & 0.91 & 0.267 & 0.60 & 0.036 \\
\hline consmfreq & 0.16 & 0.004 & 1.40 & 0.036 \\
\hline kaleqnty & -1.24 & 0.008 & -1.34 & 0.017 \\
\hline drymthd & 2.93 & 0.003 & - & - \\
\hline buydried & 0.07 & 0.000 & - & - \\
\hline frozmthd & - & - & 1.91 & 0.058 \\
\hline buyfroz & - & - & 0.08 & 0.001 \\
\hline Attribute variables & & & & \\
\hline clean & -0.17 & 0.864 & 2.15 & 0.082 \\
\hline taste & 0.88 & 0.400 & -0.96 & 0.446 \\
\hline color & 0.20 & 0.010 & 0.26 & 0.007 \\
\hline tender & 2.69 & 0.049 & -0.41 & 0.881 \\
\hline uninjured & 1.71 & 0.127 & 3.15 & 0.027 \\
\hline price & -1.34 & 0.133 & -0.02 & 0.984 \\
\hline constant & -18.72 & 0.008 & -6.88 & 0.406 \\
\hline$N$-value & & & & \\
\hline Pseudo R & & & & \\
\hline
\end{tabular}

Despite the low WTP for some forms of value-added cowpea leaves, the majority of respondents are not able to find this vegetable during the dry season. Approximately $81 \%$ of the respondents indicated that it is difficult to find cowpea leaves during the dry season and they are forced then to switch to other vegetables, namely kale, cabbage, and spinach (which are grown outside the district) and amaranth (which is produced along valley bottom and/or using irrigation within the districts, and hence is quite expensive). As a result kale is the most widely consumed vegetable in the study areas during dry periods, with approximately $84 \%(N=108)$ of the respondents indicating that they switch to kale when cowpea leaves are not available in the market.
Determinants of consumers WTP for advanced value addition: Regression results

Table 6 presents the results of Tobit regression models estimated to assess the factors conditioning consumers' WTP for value-added cowpea leaves. The models were estimated for sun-dried and frozen leaves. The dependent variable in both cases is the WTP bid (in Kenya shillings). The estimated models have a $p$-value of 0.000 , indicating that they are highly statistically significant.

Factors affecting demand for sundried cowpea leaves Starting with the sundrying model, results indicate that a number of socio-economic factors affect WTP for value addition. Specifically, respondents' age and gender can be associated with WTP for sun-drying of cowpea leaves. With other things held constant, a unit increase in the natural logarithm of age increases the willingness for sun-drying by approximately KSh3. This finding is not surprising. Cowpea leaves are particularly popular among older consumers (50 years ${ }^{5}$ and above). Among these consumers, cowpea is typically cooked in either coconut or cow milk until it loses its green color. In some cases, the cooked vegetable is boiled repeatedly for several days with sour milk, thus transforming the color to brown. This practice is common among consumers from western and coastal Kenya. Drying cowpea leaves will therefore not affect the appeal of this vegetable to such con-

5 This age is based on discussions with some consumers. 
sumers unless it significantly alters the taste. The significance of this variable may also be related to medical health reasons. The recent increase in documented cancer cases in Kenya, the perception that pesticides are not used in cowpea production, and the argument that it is rich in micronutrients, are causing a shift in diet from foods associated in the public mind with cancer (e.g., meats) to vegetables in general, and AIVs in particular, especially among urban consumers (Ng'etich, 2011). Indeed, in urban areas the rise in demand for cowpea leaves has led some leading urban supermarket chains (such as Nakumatt, Tuskys, and Uchumi) to introduce it into their green groceries sections (Okello et al., 2011). Gender also affects WTP, with data indicating that male consumers are less willing to pay additional money for value addition via sun-drying. This finding may be attributed to the fact that preparation and cooking of vegetables is mostly done by women.

Responses also indicate that awareness of sundrying as a value-addition process, the frequency of consumption of cowpea leaves in the household, and the consumer's self-reported likelihood of buying sundried vegetables will result in an increase in WTP by KSh1.60, KSh2.90 and KSh0.10, respectively, other things held constant. This finding corroborates our earlier argument that awareness influences demand for value addition and underscores the need for promoting awareness of sun-drying as a value-addition strategy among consumers. As expected, households that consume more of the substitute vegetable, kale, will pay less for sundried cowpea leaves. An increase in consumption of kale by one bundle per week reduces WTP for sundried leaves by KSh1.23, other things held constant.

Among the attribute variables, the factors affecting the stated W'TP for sun-drying are color of the leaves and tenderness of cooked leaves. The positive sign on the coefficient of the dummy variable for color suggests that consumers are generally willing to pay more for fresh green leaves, other things constant, even though its availability is seasonal. This finding suggests that consumers who care more about the color of vegetables are not willing to pay for a value-addition process that alters the color. Similarly, the results indicate that consumers are willing to pay more for tender leaves, suggesting that the sun-drying process that makes the leaves hard or fibrous will reduce demand for the value-added cowpea. At the same time, the results indicate that there is no statistical evidence to suggest that price, taste, or freedom from bruises individually affects the WTP for sundrying, although the signs are as expected. However, a Wald multiple exclusion restriction test of the hypothesis that all the attribute and preference variables have no joint effect on WTP yielded an $F$-statistic of 2.49 and $p$-value of 0.025 . These test results indicate that attribute and preference variables increase the stated WTP when acting together, but not individually. Together, they suggest that consumers desire a value-addition process that does not change some of the key attributes of fresh cowpea leaves, such as color and tenderness.

\section{Factors driving WTP for frozen compea leaves}

The results of the Tobit model estimated to assess the conditioners of WTP for frozen cowpea leaves are presented in the last two columns of Table 6. Among the socio-economic variables, education and participation in nutrition-focused consumer and/or community groups increase the WTP for the value-added (frozen) cowpea leaves. Holding other things equal, a unit increase in the natural logarithm of years of schooling increases the WTP by about KSh1.00, while participation in community groups increases WTP by KSh0.60. Results further show that the frequency with which a household consumes cowpea leaves, awareness of vegetable processing via freezing, and the selfreported likelihood of purchasing frozen vegetable all increase consumers' WTP to pay for value addition via freezing. As in the case of sun-drying, a higher quantity of kale consumed by the household reduces WTP for frozen cowpea leaves.

The attribute and preference variables that affect WTP for freezing are cleaning dirt from the leaves, color, and freedom from bruises and injuries. Notably, the coefficient on color is positive, indicating that similar to sun-drying, consumers are more concerned about color of the vegetable. Combined with the results on education, this finding suggests that those more likely to pay for frozen vegetable are the more educated women 
who are discerning about physical quality.

\section{Conclusions and Policy Implications}

This study characterizes AIV consumers and consumption, and examines the factors conditioning the demand for value-addition processes aimed at smoothing the availability of cowpea leaves. The study shows that while there are clear benefits to simple value-addition services (including using clean water to moisten cowpea leaves, selling cowpea leaves in raised beds, washing off soil, and grading and sorting the leaves), most consumers are currently not willing to pay more for such services.

The results of the estimated Tobit regression models show that WTP is affected by the consumer's age, gender, and education; their awareness of the value-addition techniques; and whether they are likely to purchase value-added vegetables of any kind. The study shows that certain attributes, notably color, tenderness, freedom from bruises, and cleanness from soil increase the demand for value-added cowpea leaves.

Several implications for community development actors interested in investing in AIVs, and in cowpeas in particular, in order to improve rural communities' food systems arise from the findings of this study. First, demand for value-added cowpea leaves exists, but there is still a sizeable share (at least $30 \%$ ) of consumers who do not currently exhibit effective demand for value-addition services in relation to cowpea leaves. This is partly because cowpea leaves consumers are unaware of various value-addition processes applicable to cowpea leaves, and because they broadly associate value addition with costliness. Two implications arise from this finding: (a) the need to create awareness of value-addition processes and provide information on the benefits of value addition, including the fact that it does not necessarily negatively affect the nutrient composition of the vegetable, and (b) the value-addition process adopted need to even out the availability of the vegetable across the year while keeping the price down to ensure it remains affordable. This is especially crucial given that majority of consumers are from low-income households. Efforts to expand production and consumption of cowpea leaves should therefore focus on promoting the value of drying and freezing the leaves to improve availability and reduce cost, particularly during the dry season, to potential consumers. Otherwise, value-chain actors will find themselves needlessly investing time and money in value-addition practices for which there will be little to no return.

The findings with respect to age, ethnicity, and education clearly point to the market potential for targeting value-addition processes at specific niche markets. They suggest that value addition via drying of leaves should be targeted at communities that typically consume cowpeas leaves in boiled brown form (such as those from western Kenya and the Mijikenda) and also older consumers (above the age of 50 years). Value addition by 
freezing should target consumers who prefer freshness and greenness of the leaves. These include more educated and younger consumers, and consumers from ethnic backgrounds who typically consume cowpea leaves mainly for health and nutritional reasons.

The findings of this study further suggest the need to use processes that conserve the color of the leaves. This is especially important in targeting the emerging middle- to high-income, educated consumers, particularly in urban areas. This group of consumers is already associated with demand for indigenous vegetables and is therefore probably more susceptible to marketing strategies related to cowpea. More expensive value-addition options such as freezing and blanching accompanied by vacuum packing can target such consumers. Urban niche markets can therefore provide a fairly lucrative outlet for AIVs. In countries like Zambia such markets are very important. In addition, gender-responsive smallholder value-chain development is required to help women, who are the majority in this chain, sustain their role in such competitive urban niche markets.

This study focused on urban and peri-urban cowpea consumers and therefore did not include poor smallholder cowpea producers who are more vulnerable to food insecurity and also form a large segment of cowpea leaves consumers. Future research should extend the investigation of WTP for value addition to cowpea producers. The study also did not include cowpea leaves consumers who buy from hawkers and kiosks, due to logistical reasons. The proportion of consumers who use this channel is unknown but may be sizeable, especially in peri-urban areas. Their inclusion in future studies could lead to a better understanding of the role value addition can play in the development of peri-urban fresh produce food systems as well. At the same time, more detailed gender analysis, based on gender-disaggregated data, is needed to understand whether and how women and men consumers differ in their demand for value addition. 


\section{References}

Abukutsa-Onyango, M. O. (2002). Market survey on African indigenous vegetables in Western Kenya. In J. M. Wesonga, T. Losenge, C. K. Ndung'u, K. Ngamau, J. B. M. Njoroge, F. K. Ombwara, \& S. G. Agong (Eds.), Proceedings of the $2^{\text {nd }}$ Horticultural Seminar on Sustainable Horticultural Production in the Tropics (pp. 39-46). Nairobi: Department of Horticulture, Jomo Kenyatta University of Agriculture and Technology. Retrieved from http://www.academia.edu/2657989/SUSTAINAB LE HORTICULTURAL PRODUCTION IN T HE TROPICS

Abukusta-Onyango, M. O. (2003). Unexploited potential of indigenous African vegetables in Western Kenya. Maseno Journal of Education Arts and Science, 4, 103-122.

Abukutsa-Onyango, M. O., Kavagi, P., Amoke, P., \& Habwe, F. O. (2010). Iron and protein content of priority African indigenous vegetables in the Lake Victoria Basin. Journal of Agricultural Science and Technology, 4(4), 67-69.

Akgüngör, S., Miran, B., \& Abay, C. (2001). Consumer willingness to pay for food safety labels in urban Turkey: A case study of pesticide residues in tomatoes. Journal of International Food and Agribusiness Marketing, 12(1), 91-107. http://dx.doi.org/10.1300/J047v12n01_05

Blend, J. R., \& Van Ravenswayy, E. O. (1998). Consumer demand foe ecolabeled apples: Survey methods and descriptive results (Staff paper 98-20). Michigan State University, East Lansing, Michigan. Retrieved from http://ageconsearch.umn.edu/ bitstream/11645/1/sp98-20.pdf

Chowdhury, S., Meenakshi, J. V., Tomlins, K. I., \& Owori, C. (2011). Are consumers in developing countries willing to pay more for micronutrientdense biofortified foods? Evidence from a field experiment in Uganda. American Journal of Agricultural Economics, 93(1), 83-97. http://dx.doi.org/10.1093/ajae/aaq121

Cummings, R. G., \& Taylor, L. O. (1999). Unbiased value estimates for environmental goods: A cheap talk design for the contingent valuation method. American Economic Review, 89(3), 649-665. http://dx.doi.org/10.1257/aer.89.3.649
Eom, Y. S. (1994). Pesticide residue risk and food safety valuation: a random utility approach. American Journal of Agricultural Economics, 76(4), 760-771.

Flyman, M. V., \& Afolayan, A. J. (2006). A survey of plants used as wild vegetables in four districts of Botswana. Ecology of Food and Nutrition, 45(6), 405-415. http://dx.doi.org/10.1080/03670240600985431

Gao, Z., \& Schroeder, T. C. (2009). Effects of label information on consumer willingness-to-pay for food attributes. American Journal of Agricultural Economics, 91(3), 795-809. http://dx.doi.org/ 10.1111/j.1467-8276.2009.01259.x

Gracia, A., Loureiro, M. L., \& Nayga, R. M. (2009). Consumers' valuation of nutritional information: a choice experiment study. Food Quality and Preference, 20(7), 463-471.

Graffham, A., \& MacGregor, J. (2009). Impact of GLOBALGAP on small-scale vegetable growers in Zambia. In A. B. de Batisti, J. MacGregor, \& A. Graffham (Eds.), Standard Bearers: Horticultural exports and private standards in Africa (pp. 57-60). London: International Institute of Environment and Development.

Hanley, N., Wright, R. E., \& Alvarez-Farizo, B. (2006). Estimating the economic value of improvements in river ecology using choice experiments: An application to the water framework directive. Journal of Environmental Management, 78(2), 183-193. http://dx.doi.org/10.1016/j.jenvman.2005.05.001

Hutchinson, M. J., Kipkosgei, L., \& Akundabweni, L. S. M. (2011). The effect of farmyard manure and calcium ammonium nitrate fertilisers on micronutrient density (iron, zinc, manganese, calcium and potassium) and seed yields of solanum villosum (black nightshade) and cleome gynandra (cat whiskers) on eutric nitisol. Journal of Agriculture, Science and Technology, 13(1), 35-52. http://www.ajol.info/index.php/jagst/index

Irungu, C., Mburu, J., Maundu, P., Grum, M., \& Hoeschle-Zeledon, I. (2007). Analysis of markets for African leafy vegetables with Nairobi and its environs and implications for farm conservation of biodiversity. Rome: Global Facilitation Unit for Underutilized Species. Johns, T., \& Sthapit, B. R. (2004). Biocultural diversity in the sustainability of developing-country food systems. Food and Nutrition Bulletin, 25(2), 143-155. 
Karanja, N. N., Njenga, M., Mutua, G. K., Lagerkvist, C. J., Kutto, E., \& Okello, J. J. (2012). Concentrations of heavy metals and pesticide residues in leafy vegetables and implications for peri-urban farming in Nairobi, Kenya. Journal of Agriculture, Food Systems, and Community Development, 3(1), 255-267. http://dx.doi.org/10.5304/jafscd.2012.031.003

Kerr, G. (2000). Contingent valuation payment cards: How many cells? (Discussion Paper No. 87). Canterbury, UK: Commerce Division, Lincoln University. Retrieved from https://researcharchive.lincoln.ac. nz/bitstream/handle/10182/532/cd dp 87.pdf

Kumar, A., Singh, H., Kumar, S., \& Mittal, S. (2011). Value chains of agricultural commodities and their role in food security and poverty alleviation-A synthesis. Agricultural Economics Research Review, 24, 169-181.

Lacaze, V., Rodríguez, E., \& Lupín, B. (2009). Risk perceptions and willingness-to-pay for organic fish chicken in Argentina. Retrieved from http://ageconsearch.umn.edu/bitstream/51016/2/ 297.pdf

Lagerkvist, C. J., Hess, S., Okello, J., Hansson, H., \& Karanja, N. (2013). Food health risk perceptions among consumers, farmers, and traders of leafy vegetables in Nairobi. Food Policy, 38, 92-104. http://dx.doi.org/10.1016/j.foodpol.2012.11.001

Lancaster, K. J. (1966). A new approach to consumer theory. Journal of Political Economy, 74(2), 132-157. http://dx.doi.org/10.1086/259131

Lippe, R. S., Mergenthaler, M., \& Isvilanonda, S. (2010). Consumer willingness to pay for pesticide safe produce: The case of cabbage and yellow mango in Thailand. International Conference on Business and Economic Research, Kuching, Sarawak, Malaysia.

List, J. A. (2001). Do explicit warnings eliminate the hypothetical bias in elicitation procedures? Evidence from field auctions for sportscards. American Economic Review, 91(5), 1498-1507. http://dx.doi.org/10.1257/aer.91.5.1498

Lusk, J. L., \& Hudson, D. (2004). Willingness-to-pay estimates and their relevance to agribusiness decision making. Review of Agricultural Economics, 26(2), 152-169. http://dx.doi.org/10.1111/j.14679353.2004.00168.x

Matenge, S. T. P., van der Merwe, D., De Beer, H., Bosman, M. J. C., \& Kruger, A. (2012). Consumers' beliefs on indigenous and traditional foods and acceptance of products made with cow pea leaves. African Journal of Agricultural Research, 7(4), 22432254.

Muhanji, G., Roothaert, R. L., Webo, C., \& Mwangi, S. (2011). African indigenous vegetable enterprises and market access for small-scale farmers in East Africa. International Journal of Agricultural Sustainability, 9(1), 194-202. http://dx.doi.org/10.3763/ijas.2010.0561

Müller, O., \& Krawinkel, M. (2005). Malnutrition and health in developing countries. Canadian Medical Association Journal, 173(3), 279-286. http://dx.doi.org/10.1503/cmaj.050342

Mundua, J. (2010). Estimation of consumer preference for compea varieties in Kumi and Soroti districts, Uganda (Unpublished master's thesis). Makerere University, Kampala, Uganda.

Ng'etich, J. (2011, October 7). Kenya: Grapples with rising cases of cancer. The Nation, Retrieved from http://allafrica.com/

Ngigi, M. W., Okello, J. J., Lagerkvist, C. L., Karanja, N. K., \& Mburu, J. (2011). Urban consumers' willingness to pay for quality of leafy vegetables along the value chain: The case of Nairobi Kale consumers, Kenya. International Journal of Business and Social Science, 2(7), 208-216. http://ijbssnet.com/ journals/Vol. 2 No. 7; Special Issue April 2011 23.pdf

Ngugi, I. K., Gitau, R., \& Nyoro, J. K. (2007). Access to high value markets by smallholder farmers of African indigenous vegetables in Kenya. London: International Institute of Environment and Development. Retrieved from http://www.fao.org/fileadmin/ user upload/ivc/docs/Access to High Value Markets_Indigenous_Vegetables.pdf

Nyagah, R. (2009). Tackling the exclusion of smallholders from fresh produce markets: A personal view. In A. B. de Batisti, J. MacGregor, \& A. Graffham (Eds.), Standard bearers: Horticultural exports and private standards in Africa (pp. 92-94). London: International Institute for Environment and Development.

Okello, J. J., Narrod, C. A., \& Roy, D. (2007). Food safety requirements in African green bean exports and their impact on small farmers (IFPRI Discussion Paper No. 737). Washington, D.C.: International Food Policy Research Institute. http://purl.umn.edu/42362 